\title{
Why CMAJ writes editorials
}

\author{
Diane Kelsall MD MEd, Matthew B. Stanbrook MD PhD, Ken Flegel MD MSc, Kirsten Patrick MB BCh DA, \\ Erin Russell MSc, Barbara Sibbald BJ
}

A 11 Canadian physicians have a responsibility to engage in health advocacy ${ }^{1}$ - and those of us who are editors at $C M A J$ are no exception. As health advocates, we are to "respond to the needs of the communities or populations [we] serve by advocating with them for system-level change in a socially accountable manner." The population we serve as editors is far bigger than that in our own practices - and we are especially privileged to have a platform that allows our voices to be heard broadly, nationally and internationally. We do not take this privilege lightly.

Editors throughout the 105 years of CMAJ have shared their views on the thorny issues of the day with readers. In the first year of the journal, an editorial called for drastic changes to a provincial medical council to protect the general public better. An editorial in 1923 had a surprisingly modern take on the use of illicit narcotics, in urging that addicts in prison be treated as patients, rather than as prisoners, and calling for greater cooperation between the federal and provincial governments to address this difficult problem.

Writing such editorials is an explicit part of our job description as senior editors. As in the past, today's editors use the journal's pages to "promote the health and well-being of the Canadian public," in keeping with CMAJ's mission. ${ }^{2}$ Recently, we have tackled problems that are particularly Canadian, such as winter driving, and wearing ski and hockey helmets, but we haven't neglected global health issues that affect us all, like climate change and antibiotic resistance.

Some readers say that we should not speak out on political issues. But many of the health problems that have affected Canadians in the past - and continue to do so today - are rooted in political decisions. It is our responsibility to speak to policy-makers, to raise awareness of important health issues, to call for meaningful change. ${ }^{1}$

A healthy democracy — and a healthy profession - depends on its citizens being regularly confronted with contrary points of view, which can be uncomfortable at times. As we have learned in clinical practice, surrounding ourselves only with those who agree with us can perpetuate error and hinder improvement.

We are not partisan. Each of us brings our unique mix of political and philosophical perspectives to the editorial table. None of us is coerced to adopt a particular editorial stance. Rather, we share a mandate to encourage governments and other policy-makers, regardless of political persuasion, to do the right thing for the health of Canadians, and if they don't, as we see it, we call them out on it. That may make us unpopular sometimes, but it is essential to our role as advocates for the Canadian public.
Some have questioned why our editorial stance on an issue may differ from that of the Canadian Medical Association (CMA). We are editorially independent from the CMA, and as such, our editorials do not represent the association's views, although frequently our views do align, unsurprisingly - we are part of the same profession, after all.

Neither do we claim to speak for Canadian physicians. Instead, we speak to our readers, whether clinicians, researchers, policy-makers or patients, in the hopes of sparking a collegial discussion. Our editorials generate many letters, which help to broaden the discussion, and we are grateful to our readers who share their views with us.

Our editorials have won many national awards, but they have also helped to precipitate action. Advocacy is a team sport - and our widespread readership has the power to effect change, locally, nationally and internationally. Our readers have engaged with us on numerous issues affecting health, including prison health, asbestos and Aboriginal health.

Some government policies have changed, some attitudes have changed, and as a consequence, some lives will have changed for the better. Although we are sometimes berated for our opinions, we are encouraged that many readers have taken the views presented in our editorials seriously over the years. In doing so, they have improved the health of Canadians.

We will continue to write editorials on issues that matter to the health of Canadians, as is our responsibility as editors of CMAJ. And we will continue to welcome responses from our readers - including those critical of our editorial positions - and to post such letters publicly, so that all may benefit from a thoughtful, respectful discourse.

\section{References}

1. Health advocate. Ottawa: The Royal College of Physicians and Surgeons of Canada; 2016. Available: www.royalcollege.ca/rcsite/canmeds/framework/canmeds-role -health-advisor-e (accessed 2016 July 21).

2. About CMAJ. Ottawa: Canadian Medical Association Journal. Available: www.cmaj. $\mathrm{ca} /$ site/misc/about.xhtml (accessed 2016 July 21).

Competing interests: See www.cmaj.ca/site/misc/cmaj_staff.xhtml.

Affiliations: Interim Editor-in-Chief (Kelsall), Deputy Editor (Stanbrook, Patrick), Senior Editor (Flegel), Assistant Editor (Russell), News and Humanities Editor (Sibbald), CMAJ

\section{Correspondence to: CMAJ editor, pubs@cmaj.ca}

Editor's note: If you have any suggestions for editorial topics, please email us at editor@cmaj.ca.

CMAJ 2016. DOI:10.1503/cmaj.160878 